\title{
Article \\ Deriving Soil Quality Criteria of Chromium Based on Species Sensitivity Distribution Methodology
}

\author{
Yuxia Liu ${ }^{1}$, Qixing Zhou ${ }^{2, *}$, Yi Wang ${ }^{2}$, Siwen Cheng ${ }^{3}$ and Weiduo Hao ${ }^{4}$ \\ 1 Beijing Key Laboratory of Oil and Gas Pollution Control, China University of Petroleum, \\ Beijing 102249, China; liuyuxia_mm@163.com \\ 2 Key Laboratory of Pollution Processes and Environmental Criteria (Ministry of Education), \\ College of Environmental Science and Engineering, Nankai University, Tianjin 300071, China; \\ 13752443261@126.com \\ 3 School of Chemistry and Environmental Engineering, Wuhan Polytechnic University, Wuhan 430023, China; \\ Aa973831917@126.com \\ 4 Department of Earth and Atmospheric Sciences, University of Alberta, Edmonton, AB T6G 2E3, Canada; \\ whao@ualberta.ca \\ * Correspondence: zhouqx@nankai.edu.cn
}

Citation: Liu, Y.; Zhou, Q.; Wang, Y.; Cheng, S.; Hao, W. Deriving Soil Quality Criteria of Chromium Based on Species Sensitivity Distribution Methodology. Toxics 2021, 9, 58. https://doi.org/10.3390/ toxics 9030058

Academic Editor: Octavio Pérez Luzardo

Received: 8 February 2021

Accepted: 26 February 2021

Published: 16 March 2021

Publisher's Note: MDPI stays neutral with regard to jurisdictional claims in published maps and institutional affiliations.

Copyright: (c) 2021 by the authors. Licensee MDPI, Basel, Switzerland. This article is an open access article distributed under the terms and conditions of the Creative Commons Attribution (CC BY) license (https:// creativecommons.org/licenses/by/ $4.0 /)$.

\begin{abstract}
Chromium (Cr) is one of the most severe heavy metal contaminants in soil, and it seriously threatens ecosystems and human health through the food chain. It is fundamental to collect toxicity data of $\mathrm{Cr}$ before developing soil quality criteria/standards in order to efficiently prevent health risks. In this work, the short-term toxic effects of $\mathrm{Cr}(\mathrm{VI})$ and $\mathrm{Cr}(\mathrm{III})$ on the root growth of eleven terrestrial plants were investigated. The corresponding fifth percentile hazardous concentrations $\left(\mathrm{HC}_{5}\right)$ by the best fitting species sensitivity distribution (SSD) curves based on the tenth percentile effect concentrations $\left(\mathrm{EC}_{10}\right)$ were determined to be 0.60 and $4.51 \mathrm{mg} / \mathrm{kg}$ for $\mathrm{Cr}$ (VI) and $\mathrm{Cr}$ (III), respectively. Compared to the screening level values worldwide, the $\mathrm{HC}_{5}$ values in this study were higher for $\mathrm{Cr}(\mathrm{VI})$ and lower for $\mathrm{Cr}(\mathrm{III})$ to some extent. The results provide useful toxicity data for deriving national or local soil quality criteria for trivalent and hexavalent $\mathrm{Cr}$.
\end{abstract}

Keywords: ecological risk assessment; species sensitivity distribution (SSD); Cr; toxicity

\section{Introduction}

Chromium $(\mathrm{Cr})$ is one of the most common heavy metal contaminants in soil, sediments, and groundwater. It occurs in several oxidation states ranging from $\mathrm{Cr}^{2-}$ to $\mathrm{Cr}^{6+}$, with trivalent $\left(\mathrm{Cr}^{3+}\right)$ and hexavalent $\left(\mathrm{Cr}^{6+}\right)$ states being the most common and stable in terrestrial environments. Both oxidation states are excessively released into the environment due to a variety of industrial applications and anthropogenic activities, such as mining, metallurgy, tanneries, pigment-producing plants, fossil fuel combustion, and chemical fertilizers [1-8]. Chromium can be either beneficial or toxic to plants, animals and humans, depending on its oxidation state and concentrations. At low concentrations, $\mathrm{Cr}$ (III) is considered to be an essential component in the metabolism of plants, e.g., the synthesis of amino and nucleic acids [3,9]. For example, $\mathrm{Yu}$ and $\mathrm{Gu}(2007)$ indicated that 2-5 mg/L $\mathrm{Cr}$ (III) increased the transpiration rate and chlorophyll contents of hybrid willow [10]. However, $\mathrm{Cr}$ (III) at increased concentrations may prohibit metabolic processes and metalloenzyme systems in living organisms [10-13]. For example, do Nascimento et al. (2018) reported that $200 \mathrm{mg} / \mathrm{kg}$ of $\mathrm{Cr}$ (III) in soil increased the expression of $p s b \mathrm{~A}$ and $p s b \mathrm{O}$ genes, which were responsible for electron transfer and oxygen evolution and directly influenced the photosynthesis and growth of young cocoa plants [12]. Compared to $\mathrm{Cr}$ (III), $\mathrm{Cr}$ (VI) compounds have higher solubility and oxidizing potential, and are known as extremely toxic carcinogens that may cause death to animals and humans [11]. Hexavalent $\mathrm{Cr}$ complexes can easily cross cellular membranes by means of sulfate ionic channels, and undergo 
immediate reduction reactions leading to the formation of reactive intermediates, which are harmful to cell organelles, proteins and nucleic acids [13-15].

Heavy metal pollutants, such as $\mathrm{Cr}$, have been paid considerable attention because of their toxicity, persistence and biological accumulation, which can generate a serious threat to ecosystems and human health through the food chain. Soil quality criteria are derived based on an upper-limit concentration that shows no undesirable or harmful effects [16-18]. It is generally considered that contamination below the soil quality criteria in soil or sediments leads to tolerable or minimal human health and ecological risks in the long-term $[16,18,19]$. However, countries in the world generally derived the screening level values without distinguishing the chemical valence and fractionation of contaminants. It is not enough for predicting the toxicity of pollutants such as As, Cr, Se and V since these trace metals have different valences with different $\mathrm{Eh}$ and $\mathrm{pH}$, and can exist as either cations or anions in the soil environment $[4,20,21]$. It is obvious that metals existing as cationic species have a greater propensity to associate with the solid and are less bioavailable, while anionic metals enter into the pore-water easily and are more soluble [22].

The species sensitivity distribution (SSD) method is widely used in ecological risk assessment and the development of soil quality criteria. The SSD analysis is based on the statistically cumulative probability distribution of toxicity data for multiple species $[23,24]$. One function of SSD analysis is to calculate the concentration of a contaminant at which a specified proportion of species will be affected, referred to as the hazardous concentration $(\mathrm{HC})$ for $\mathrm{p} \%$ of species $\left(\mathrm{HC}_{\mathrm{p}}\right)$ [25]. For example, $\mathrm{HC}_{5}$ means a point estimation of the hazardous concentration for $5 \%$ of species or the $95 \%$ protection level $[26,27]$. The SSD is dependent upon available datasets and can differ in the type of distribution, taxonomic diversity, and sample size.

Vegetables and wheats are an essential part of a healthy and balanced ecosystem, and their phytotoxicity tests are required for risk assessment and environmental monitoring. Phytotoxicity tests include the effects of a contaminant on seed germination, seedling (shoot and root) development, biomass production or other physiological functions [28,29]. It was previously reported that root biomass was the most sensitive tissue to $\mathrm{Cr}$, and $\mathrm{Cr}$ predominantly accumulated in plant root tissue, with very limited translocation to the shoot [21,28]. Wong and Bradshaw (1982) indicated that the root growth of Lolium Perenne can be ceased due to metal pollution (e.g., $\mathrm{Cu}, \mathrm{Ni}, \mathrm{Mn}, \mathrm{Pb}, \mathrm{Cd}$ and $\mathrm{Cr}$ ) [30]. As a result, root growth may be the most rapid and sensitive response to $\mathrm{Cr}$ contamination in soil since the root is the first and most direct plant tissue to contact $\mathrm{Cr}$ contamination [30]. The aim of this work was: (1) to enrich the database of $\mathrm{Cr}$ toxicity and determine the effect of $\mathrm{Cr}(\mathrm{VI})$ and $\mathrm{Cr}(\mathrm{III})$ on a variety of widely cultured vegetables and crops; (2) to derive the soil quality criteria value of $\mathrm{Cr}(\mathrm{VI})$ and $\mathrm{Cr}(\mathrm{III})$ based on the SSD method; and (3) to compare the criteria values with other countries worldwide and provide a scientific base for the development of soil quality standards.

\section{Materials and Methods}

\subsection{Soils and Chemicals}

The soil sample was collected from Jixian, Tianjin city, without prehistory of $\mathrm{Cr}$ contamination. This region was originally developed from the parental material basalt (Alfisol). In the laboratory, samples were air-dried, sieved through a 5-mm mesh, homogenized using a scoop, and then stored in a glass bottle until their use. Basic soil properties were characterized using standard methods [31] and are shown in Table 1.

Table 1. Basic properties of the tested soil.

\begin{tabular}{ccccc}
\hline pH & $\begin{array}{c}\text { Organic Matter } \\
(\mathbf{g} / \mathbf{k g})\end{array}$ & $\begin{array}{c}\text { Cation Exchange } \\
\text { Capacity }(\mathbf{c m o l} / \mathbf{k g})\end{array}$ & $\begin{array}{c}\text { Total Nitrogen } \\
(\mathbf{g} / \mathbf{k g})\end{array}$ & $\begin{array}{c}\text { Total } \\
\text { Phosphorus (\%) }\end{array}$ \\
\hline 7.1 & 16.77 & 29.5 & 1.48 & 1.48 \\
\hline
\end{tabular}


Analytical grade $\mathrm{CrCl}_{3} \cdot 6 \mathrm{H}_{2} \mathrm{O}$ and $\mathrm{K}_{2} \mathrm{Cr}_{2} \mathrm{O}_{7}$ ( $>99 \%$ purity) were used as $\mathrm{Cr}(\mathrm{III})$ and $\mathrm{Cr}(\mathrm{VI})$ sources.

\subsection{Short-Term Toxicity Tests}

Chromium toxicity tests were performed for 11 different crops, including: pakchoi cabbage (Brassica rapa chinensis), tomato (Solanum lycopersicum), wheat (Triticum aestivum L.), chili (Capsicum annuum L.), eggplant (Solanum melongena L.), celery (Apium graveolens L.), chive (Allium schoenoprasum L.), lettuce (Lactuca sativa L.), cucumber (Cucumis sativus L.), radish (Raphanus sativus L.), and spinach (Spinacia oleracea L.). Among these plants, pakchoi cabbage, lettuce, spinach and chive are leafy vegetables, tomato, chili and eggplant are solanaceous vegetables, celery is a stem vegetable, and cucumber is a gourd vegetable. All plant seeds were purchased from the Chinese Academy of Agricultural Sciences (located in Tianjin city). Before planting, the plant seeds were pre-treated by sterilizing in $3 \% \mathrm{H}_{2} \mathrm{O}_{2}$ for $20 \mathrm{~min}$ to prevent fungal contamination, washing with sterilized deionized water several times, and then drying softly with tissue (KIMTECH-Clark).

The initial concentrations of $\mathrm{Cr}(\mathrm{III})$ and $\mathrm{Cr}(\mathrm{VI})$ for test plants are presented in Table 2. The initial concentrations of $\mathrm{Cr}(\mathrm{III})$ and $\mathrm{Cr}(\mathrm{VI})$ were in accordance with current situations and levels of soil contamination $[5,6]$, and fell into the range to ensure $65 \%$ of germination rate for the test plant according to a pilot experiment. About $50 \mathrm{~g}$ of soil was weighed and transferred into a culture dish (diameter: $90 \mathrm{~mm}$ ). Each treatment was performed in triplicate to minimize experimental errors. Each culture dish was planted with 15 sterilized seeds and cultured in an incubator (LRH-250-Gb, made in Guangdong, China). The plants were illuminated with a light/dark cycle of approximately $15 / 9 \mathrm{~h}$ and the temperature was kept around $25 \pm 1{ }^{\circ} \mathrm{C}$. All culture dishes were watered and adjusted to $60 \%$ of maximal holding capacity with distilled water. Soil without $\mathrm{Cr}$ supply was used as a control treatment. When the length of plant roots in the control reached $20 \mathrm{~mm}$ and germination rate $>65 \%$ for each species, the $\mathrm{Cr}$ exposure experiment was finished. For each seed, the elongation of both root and seedling exceeding $3 \mathrm{~mm}$ was considered to be a successful germination. Generally, the plants need around 2 weeks to meet the standard of successful germination before harvesting. The plants were then removed and rinsed with distilled water. The root elongation of all treatments was measured and calculated. Root architectural traits were analyzed using the software WinRHIZO (WinRHIZO PRP2012, Regents Instruments Inc., Quebec, QC, Canada).

Table 2. Initial concentration of $\mathrm{Cr}(\mathrm{III})$ and $\mathrm{Cr}(\mathrm{VI})$ for test plants.

\begin{tabular}{ccc}
\hline Species & Cr(III) $\mathbf{~ m g} / \mathbf{k g}$ & Cr(VI) mg/kg \\
\hline Brassica rapa chinensis & $0,10,50,100,200,300,400,500$ & $0,1,2,4,6,8,10,20$ \\
Lactuca sativa L. & $0,50,100,200,400,600,800,1000$ & $0,1,2,4,6,8,10,20$ \\
Allium schoenoprasum L. & $0,10,20,50,100,150,200,300$ & $0,1,2,4,6,8,10,20$ \\
Triticum aestivum L. & $0,100,200,400,600,800,1000,1500$ & $0,1,2.5,5,10,20,40,60,80$ \\
Solanum lycopersicum & $0,50,100,200,300,400,500,600$ & $0,1,2,4,6,8,10,20$ \\
Raphanus sativus L. & $0,100,200,400,600,800,1000,1500$ & $0,1,2.5,5,10,15,20,40$ \\
Capsicum annuum L. & $0,50,100,200,400,600,800,1000$ & $0,2.5,5,10,15,20,30,40$ \\
Solanum melongena L. & $0,50,100,200,400,600,800,1000$ & $0,2,4,6,8,10,15,20$ \\
Spinacia oleracea L. & $0,100,200,400,600,800,1000,1500$ & $0,1,2,5,10,15,20,30$ \\
Apium graveolens L. & $0,50,100,200,400,600,800,1000$ & $0,2.5,5,7.5,10,15,30$ \\
Cucumis sativus & $0,100,200,400,600,800,1000,1500$ & $0,5,10,15,20,30,40,80$ \\
\hline
\end{tabular}

\subsection{Species Sensitivity Distribution (SSD)}

Species sensitivity distribution (SSD) curves were constructed based on short-term toxicity data for 11 terrestrial species. The resulting data were ranked, and the rank percentiles were determined for each data point. Data points with the same concentration 
were recommended to be assigned separate, sequential ranks, rather than calculating tied ranks [32]. Rank percentiles were calculated using the following equation:

$$
j=\frac{i}{(n+1)} \times 100
$$

where $j=$ rank percentile; $i=$ rank of the data point in the data set; $n=$ total number of data points in the data set.

Toxicity data such as $\mathrm{EC}_{10}$, NOEC (no observed effect concentration), LOEC (lowest observed effect concentration) or MATC (maximum acceptable toxic concentration) were required and fitted to SSD curves. In this study, we determined the SSD curves by both the Slogistic and the Exponential model using software of Origin8.6. The distribution model was fitted to toxicity data points and evaluated with the adjusted coefficient of determination $\mathrm{R}^{2}$; the higher the $\mathrm{R}^{2}$, the better the goodness of fit.

\subsection{Statistic Analysis and Data Integration}

All statistical analyses were performed by SPSS20.0. Graphs were prepared using Origin8.6. The treatment means were compared using Duncan's multiple range test (DMRT) and taking $p<0.05$ as significant. EC values and their confidence intervals were calculated by a log concentration-logit effect regression model, as described previously [33].

\section{Results}

\subsection{Species Sensitivity to Short-Term Toxicity of $\mathrm{Cr}$}

\subsubsection{Short-Term Toxicity Tests of $\mathrm{Cr}(\mathrm{VI})$}

Short-term toxicity tests of $\mathrm{Cr}(\mathrm{VI})$ to eleven terrestrial plants indicated by root growth inhibition are shown in Figure 1 and Table 3. Different plants displayed variable toxic responses to $\mathrm{Cr}(\mathrm{VI})$. The leafy vegetables, such as pakchoi cabbage, lettuce and chive, were the most sensitive species to $\mathrm{Cr}(\mathrm{VI})$, and the root inhibition rates were positively correlated with the concentration of $\mathrm{Cr}(\mathrm{VI})$. Specifically, the root inhibition rate of pakchoi cabbage reached as high as $30 \%$ under $2 \mathrm{mg} / \mathrm{kg}$ of $\mathrm{Cr}(\mathrm{VI})$ treatment, and the root inhibition rate exceeded $50 \%$ under $6 \mathrm{mg} / \mathrm{kg}$ of $\mathrm{Cr}(\mathrm{VI})$ treatment. The $\mathrm{EC}_{10}$ and $\mathrm{EC}_{20}$ for pakchoi cabbage were lower than $0.65 \mathrm{mg} / \mathrm{kg}$ and $1.13 \mathrm{mg} / \mathrm{kg}$, respectively. For spinach, $10 \mathrm{mg} / \mathrm{kg}$ of $\mathrm{Cr}(\mathrm{VI})$ led to around $60 \%$ root inhibition rate, then the inhibition rate fluctuated when the concentration of $\mathrm{Cr}(\mathrm{VI})$ increased further. Wheat had relatively lower sensitivity to $\mathrm{Cr}(\mathrm{VI})$ compared to leafy vegetables, and the $\mathrm{EC}_{10}$ and $\mathrm{EC}_{20}$ for wheat were $1.50 \mathrm{mg} / \mathrm{kg}$ and $2.25 \mathrm{mg} / \mathrm{kg}$, respectively. By contrast, the solanaceous vegetables, such as chili, tomato and eggplant, showed less sensitivity to $\mathrm{Cr}(\mathrm{VI})$, and the root inhibition rate was linearly correlated to $\mathrm{Cr}(\mathrm{VI})$ concentration. For example, the $\mathrm{Cr}(\mathrm{VI})$ concentration which resulted in a 30\% root inhibition rate was lower than $5 \mathrm{mg} / \mathrm{kg}$ for all three solanaceous vegetables, and the $\mathrm{Cr}(\mathrm{VI})$ concentration which led to a $50 \%$ root inhibition rate was around $10 \mathrm{mg} / \mathrm{kg}$. The $\mathrm{EC}_{10}$ and $\mathrm{EC}_{20}$ for solanaceous vegetables ranged around $1.55-2.78 \mathrm{mg} / \mathrm{kg}$ and $2.61-3.71 \mathrm{mg} / \mathrm{kg}$, respectively. Stem vegetables (celery) and gourd vegetables (cucumber) showed the least sensitivity to $\mathrm{Cr}(\mathrm{VI})$. The root inhibition rate for celery was not obvious at $\mathrm{Cr}(\mathrm{VI})$ concentrations lower than $10 \mathrm{mg} / \mathrm{kg}$. Intrudingly, $10 \mathrm{mg} / \mathrm{kg}$ of $\mathrm{Cr}(\mathrm{VI})$ supply seemed to enhance the growth of cucumber root. The $\mathrm{EC}_{10}$ and $\mathrm{EC}_{20}$ for cucumber even exceeded $12.83 \mathrm{mg} / \mathrm{kg}$ and $16.62 \mathrm{mg} / \mathrm{kg}$, respectively. The effect of $\mathrm{Cr}(\mathrm{VI})$ on the root growth of the above plants generally followed the order of pakchoi cabbage $>$ lettuce $>$ chive $>$ wheat $>$ tomato $>$ radish $>$ chili $>$ eggplant $>$ spinach $>$ celery $>$ cucumber. Leafy vegetables (e.g., pakchoi cabbage, lettuce and chive) might be the primary affected plants under $\mathrm{Cr}(\mathrm{VI})$ contamination, while the root growth of stem vegetables (celery) and gourd vegetables (cucumber) might be insensitive to $\mathrm{Cr}(\mathrm{VI})$ contamination. 

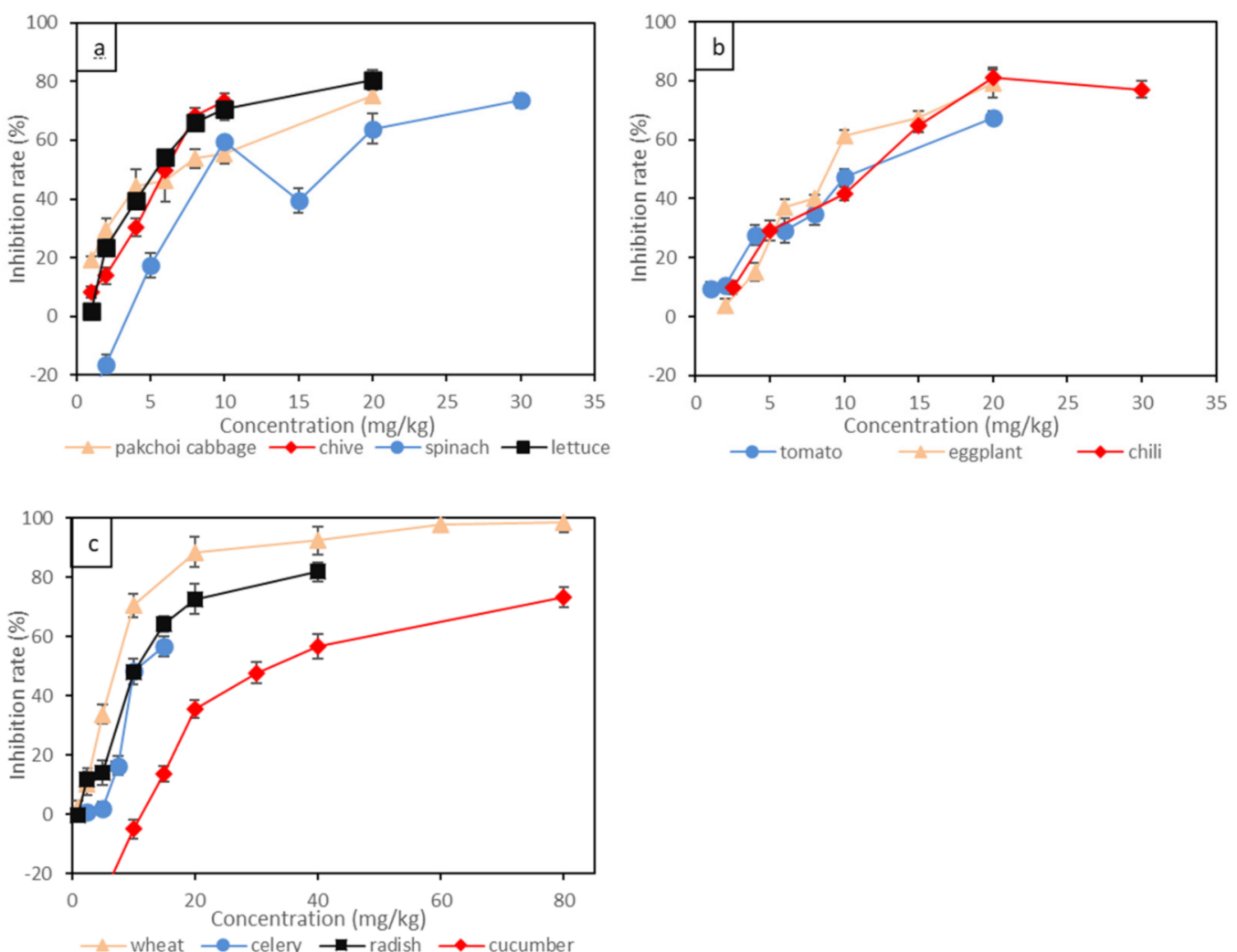

Figure 1. The inhibition rate of $\mathrm{Cr}(\mathrm{VI})$ on root elongation of 11 plants: (a) leafy vegetables; (b) solanaceous vegetables; (c) wheat, gourd vegetable and stem vegetable. Bars represent standard error $(n=3)$.

Table 3. Inhibition effects of $\mathrm{Cr}(\mathrm{VI})$ on root elongation of 11 terrestrial plants.

\begin{tabular}{ccccc}
\hline Species & Rank & $\mathbf{E C}_{\mathbf{1 0}} \mathbf{~} \mathbf{~ g / k g}$ & Rank & $\mathbf{E C}_{\mathbf{2 0}} \mathbf{~ m g} / \mathbf{k g}$ \\
\hline Brassica rapa chinensis & 1 & $0.65(0.55 \sim 0.76)$ & 1 & $1.13(0.97 \sim 1.33)$ \\
Lactuca sativa L. & 2 & $1.26(1.10 \sim 1.44)$ & 2 & $1.81(1.58 \sim 2.07)$ \\
Allium schoenoprasum L. & 3 & $1.42(1.01 \sim 2.00)$ & 3 & $1.98(1.41 \sim 2.80)$ \\
Triticum aestivum L. & 4 & $1.50(1.18 \sim 1.91)$ & 4 & $2.25(1.77 \sim 2.86)$ \\
Solanum lycopersicum & 5 & $1.55(1.10 \sim 2.18)$ & 5 & $2.61(1.85 \sim 3.67)$ \\
Raphanus sativus L. & 6 & $2.14(1.62 \sim 2.83)$ & 6 & $3.19(2.41 \sim 4.22)$ \\
Capsicum annuum L. & 7 & $2.63(1.99 \sim 3.46)$ & 7 & $3.67(2.78 \sim 4.83)$ \\
Solanum melongena L. & 8 & $2.78(2.26 \sim 3.42)$ & 8 & $3.71(3.02 \sim 4.57)$ \\
Spinacia oleracea L. & 9 & $3.71(2.83 \sim 4.86)$ & 9 & $5.13(3.91 \sim 6.71)$ \\
Apium graveolens L. & 10 & $4.39(2.30 \sim 8.38)$ & 10 & $5.87(3.07 \sim 11.22)$ \\
Cucumis sativus & 11 & 12.83 & 11 & 16.62 \\
& & $(10.88 \sim 15.13)$ & & $(14.09 \sim 19.61)$ \\
\hline
\end{tabular}

Note: Values are given as means with $95 \%$ confidence limits.

\subsubsection{Short-Term Toxicity Tests of Cr(III)}

As indicated by our experimental results, the root inhibition rate was positively correlated to $\mathrm{Cr}$ (III) concentration, as shown in Figure 2 and Table 4. Pakchoi cabbage and chive showed the most significant responses to $\mathrm{Cr}$ (III) toxins, and $50 \mathrm{mg} / \mathrm{kg}$ of $\mathrm{Cr}$ (III) led to more than $20 \%$ root inhibition. A total of $300 \mathrm{mg} / \mathrm{kg}$ of $\mathrm{Cr}$ (III) led to more than $50 \%$ root inhibition for chive and $35 \%$ root inhibition for pakchoi cabbage. The $\mathrm{EC}_{10}$ and $\mathrm{EC}_{20}$ for pakchoi cabbage and chive ranged around $5.62-11.84 \mathrm{mg} / \mathrm{kg}$ and $24.21-36.56 \mathrm{mg} / \mathrm{kg}$, respectively. By contrast, solanaceous vegetables were less sensitive to $\mathrm{Cr}(\mathrm{III})$ compared to other studied species. For example, eggplant was only sensitive to $\mathrm{Cr}$ (III) at concentrations lower than $100 \mathrm{mg} / \mathrm{kg}$, and the root growth was less affected above $100 \mathrm{mg} / \mathrm{kg}$ of $\mathrm{Cr}(\mathrm{III})$. The $\mathrm{EC}_{10}$ and $\mathrm{EC}_{20}$ for eggplant were $16.78 \mathrm{mg} / \mathrm{kg}$ and $24.71 \mathrm{mg} / \mathrm{kg}$, respec- 
tively. The root inhibition rate of tomato was linearly correlated to $\mathrm{Cr}(\mathrm{III})$ concentration, with $200 \mathrm{mg} / \mathrm{kg}$ of $\mathrm{Cr}$ (III) leading to $30 \%$ root inhibition and $500 \mathrm{mg} / \mathrm{kg}$ of $\mathrm{Cr}$ (III) leading to $50 \%$ root inhibition. Among the vegetables studied, the root growth of the gourd vegetable (cucumber) and the root vegetable (radish) showed the least sensitivity to $\mathrm{Cr}$ (III). For example, $500 \mathrm{mg} / \mathrm{kg}$ of $\mathrm{Cr}$ (III) supply led to less than $50 \%$ root growing inhibition for cucumber, and $500 \mathrm{mg} / \mathrm{kg}$ of $\mathrm{Cr}$ (III) supply only led to less than $30 \%$ root inhibition for radish. The $\mathrm{EC}_{10}$ and $\mathrm{EC}_{20}$ for radish were $189.10 \mathrm{mg} / \mathrm{kg}$ and $328.60 \mathrm{mg} / \mathrm{kg}$, respectively. It is interesting that $\mathrm{Cr}(\mathrm{III})$ posed an insignificant impact on the growth of leafy vegetables such as spinach, with $500 \mathrm{mg} / \mathrm{kg}$ of $\mathrm{Cr}$ (III) supply leading to less than $30 \%$ root inhibition, and the $\mathrm{EC}_{10}$ and $\mathrm{EC}_{20}$ were as high as $113.10 \mathrm{mg} / \mathrm{kg}$ and $187.20 \mathrm{mg} / \mathrm{kg}$, respectively. Wheat was also insensitive to $\mathrm{Cr}(\mathrm{III})$, with $1000 \mathrm{mg} / \mathrm{kg}$ of $\mathrm{Cr}$ (III) supply leading to less than $50 \%$ root inhibition. The effect of $\mathrm{Cr}(\mathrm{VI})$ on the root growth of the above plants generally followed the order of pakchoi cabbage $>$ chive $>$ eggplant $>$ celery $>$ tomato $>$ lettuce $>$ chili $>$ cucumber $>$ wheat $>$ spinach $>$ radish. The root growth of leafy vegetables (e.g., pakchoi cabbage and chive) was easily affected by $\mathrm{Cr}$ (III) contamination, while root vegetables (e.g., radish) endured high concentrations of $\mathrm{Cr}$ (III) contamination.
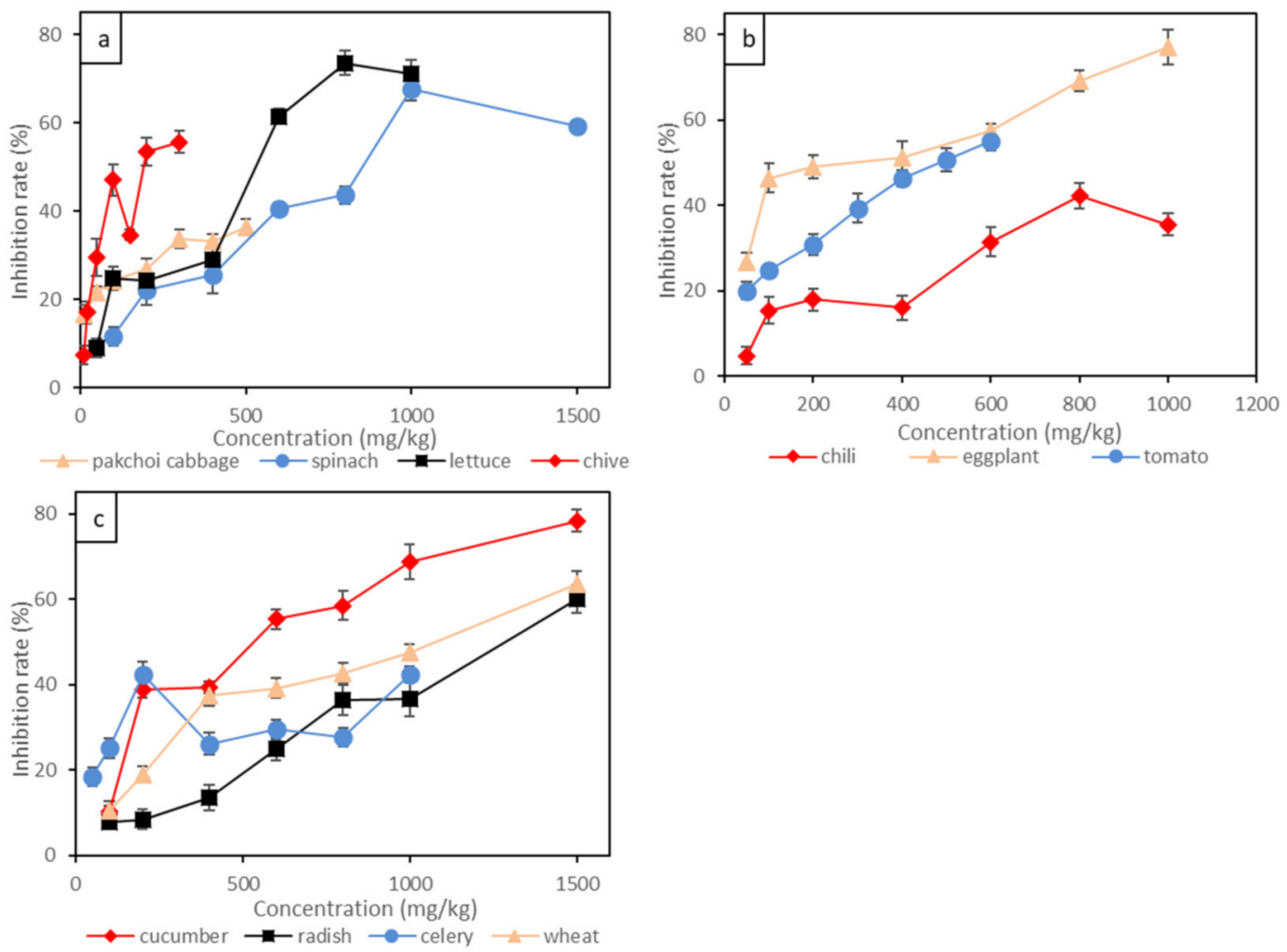

Figure 2. The inhibition rate of $\mathrm{Cr}(\mathrm{III})$ on root elongation of 11 plants: (a) leafy vegetables; (b) solanaceous vegetables; (c) wheat, gourd vegetable and stem vegetable. Bars represent standard error $(n=3)$.

Table 4. Inhibition effects of $\mathrm{Cr}(\mathrm{III})$ on root elongation of 11 terrestrial plants.

\begin{tabular}{|c|c|c|c|c|}
\hline Species & Rank & $\mathrm{EC}_{10} \mathrm{mg} / \mathrm{kg}$ & Rank & $\mathrm{EC}_{20} \mathrm{mg} / \mathrm{kg}$ \\
\hline Brassica rapa chinensis & 1 & $5.62(4.62 \sim 6.98)$ & 3 & $\begin{array}{c}36.56 \\
(29.12 \sim 46.63)\end{array}$ \\
\hline Allium schoenoprasum L. & 2 & $\begin{array}{c}11.84 \\
(8.53 \sim 16.45)\end{array}$ & 1 & $\begin{array}{c}24.21 \\
(17.44 \sim 33.62)\end{array}$ \\
\hline Solanum melongena $\mathrm{L}$. & 3 & $\begin{array}{c}16.78 \\
(13.05 \sim 22.21)\end{array}$ & 2 & $\begin{array}{c}24.71 \\
(16.97 \sim 35.98)\end{array}$ \\
\hline
\end{tabular}


Table 4. Cont.

\begin{tabular}{|c|c|c|c|c|}
\hline Species & Rank & $\mathrm{EC}_{10} \mathrm{mg} / \mathrm{kg}$ & Rank & $\mathrm{EC}_{20} \mathrm{mg} / \mathrm{kg}$ \\
\hline Apium graveolens L. & 4 & $\begin{array}{c}24.59 \\
(21.02 \sim 29.54)\end{array}$ & 4 & $\begin{array}{c}54.52 \\
(39.31 \sim 75.63)\end{array}$ \\
\hline Solanum lycopersicum & 5 & $\begin{array}{c}32.35 \\
(25.00 \sim 41.86)\end{array}$ & 5 & $\begin{array}{c}65.16 \\
(50.36 \sim 84.32)\end{array}$ \\
\hline Lactuca sativa $\mathrm{L}$. & 6 & $\begin{array}{c}65.72 \\
(41.86 \sim 103.20)\end{array}$ & 6 & $\begin{array}{c}105.10 \\
(66.96 \sim 165.10)\end{array}$ \\
\hline Capsicum annuum L. & 7 & $\begin{array}{c}84.68 \\
(51.90 \sim 138.20)\end{array}$ & 10 & $\begin{array}{c}215.60 \\
(132.10 \sim 351.70)\end{array}$ \\
\hline Cucumis sativus & 8 & $\begin{array}{c}85.58 \\
(67.52 \sim 108.50)\end{array}$ & 7 & $\begin{array}{c}131.70 \\
(103.90 \sim 166.90)\end{array}$ \\
\hline Triticum aestivum $\mathrm{L}$. & 9 & $\begin{array}{c}108.30 \\
(87.17 \sim 134.70)\end{array}$ & 9 & $\begin{array}{c}187.40 \\
(150.80 \sim 232.90)\end{array}$ \\
\hline Spinacia oleracea L. & 10 & $\begin{array}{c}113.10 \\
(74.35 \sim 171.90)\end{array}$ & 8 & $\begin{array}{c}187.20 \\
(123.00 \sim 284.70)\end{array}$ \\
\hline Raphanus satious L. & 11 & $\begin{array}{c}189.10 \\
(115.90 \sim 308.30)\end{array}$ & 11 & $\begin{array}{c}328.60 \\
(201.50 \sim 535.80)\end{array}$ \\
\hline
\end{tabular}

Note: Values are given as means with $95 \%$ confidence limits.

\subsection{Ecological Risk Assessment Based on Species Sensitivity Distributions (SSD)}

The details of formulas and parameters for SSD curves based on the Slogistic and the Exponential model are shown in Table 5. The fitted SSD curves for $\mathrm{Cr}(\mathrm{VI})$ and $\mathrm{Cr}(\mathrm{III})$ are shown in Figures 3 and 4, respectively. For $\mathrm{Cr}(\mathrm{VI})$ and $\mathrm{Cr}(\mathrm{III})$, two types of SSD curves were fitted: SSD-EC 10 and SSD-EC 20 . From each SSD-EC $\mathrm{C}_{\mathrm{x}}$ curve, $\mathrm{HC}_{5}$ and $\mathrm{HC}_{10}$ were numerically derived. The $\mathrm{HC}_{5}$ values based on the $\mathrm{EC}_{10}$ of the eleven plants were $0.60 \mathrm{mg} / \mathrm{kg}$ and $4.51 \mathrm{mg} / \mathrm{kg}$ for $\mathrm{Cr}(\mathrm{VI})$ and $\mathrm{Cr}(\mathrm{III})$, respectively. Furthermore, the $\mathrm{HC}_{10}$ values based on the eleven plants were $0.83 \mathrm{mg} / \mathrm{kg}$ and $16.98 \mathrm{mg} / \mathrm{kg}$ for $\mathrm{Cr}(\mathrm{VI})$ and $\mathrm{Cr}(\mathrm{III})$, respectively. The $\mathrm{HC}$ values for $\mathrm{Cr}(\mathrm{VI})$ were far less than $\mathrm{Cr}(\mathrm{III})$, indicating the higher toxicity of $\mathrm{Cr}(\mathrm{VI})$ to tested plants than $\mathrm{Cr}(\mathrm{III})$.

Table 5. The models and parameters of curve fitting and the values of $\mathrm{HC}_{5}$ and $\mathrm{HC}_{10}$ for chromium.

\begin{tabular}{|c|c|c|c|c|}
\hline \multirow[t]{2}{*}{ Contaminants } & \multicolumn{2}{|c|}{$\mathrm{Cr}(\mathrm{VI})$} & \multicolumn{2}{|c|}{$\mathrm{Cr}(\mathrm{III})$} \\
\hline & $\mathrm{EC}_{10}$ & $\mathrm{EC}_{20}$ & $\mathrm{EC}_{10}$ & $\mathrm{EC}_{20}$ \\
\hline Model & Slogistic1 & Slogistic3 & Exponential & Exponential \\
\hline Formula & $\begin{array}{c}\mathrm{y}=\mathrm{a} /(1+\exp \\
\left.\left(-\mathrm{k} \times\left(\mathrm{x}-\mathrm{x}_{\mathrm{c}}\right)\right)\right) \\
\mathrm{a}=93.04\end{array}$ & $\begin{array}{c}y=a /(1+b \times \\
\exp (-k \times x)) \\
a=9275\end{array}$ & $\begin{array}{c}\mathrm{y}=\mathrm{y}_{0}+\mathrm{A} \times \exp \\
\left(\mathrm{R}_{0} \times \mathrm{x}\right) \\
\mathrm{y}=-2950\end{array}$ & $\begin{array}{c}\mathrm{y}=\mathrm{y}_{0}+\mathrm{A} \times \exp \\
\left(\mathrm{R}_{0} \times \mathrm{x}\right) \\
\mathrm{y}=-11064\end{array}$ \\
\hline Parameter & $x_{c}=0.30$ & $\mathrm{~b}=18.30$ & $\mathrm{~A}=20.69$ & $\mathrm{~A}=67.19$ \\
\hline & $k=5.59$ & $k=6.33$ & $\mathrm{R}_{0}=0.79$ & $\mathrm{R}_{0}=0.44$ \\
\hline $\mathrm{R}^{2}$ & 0.97 & 0.99 & 0.97 & 0.98 \\
\hline $\mathrm{HC}_{5}$ & 0.60 & 1.01 & 4.51 & 6.65 \\
\hline $\mathrm{HC}_{10}$ & 0.83 & 1.34 & 16.98 & 21.33 \\
\hline
\end{tabular}

Note: $\mathrm{y}$ is the cumulative probability of species, $\mathrm{x}$ is the mean of the $\log _{10} \mathrm{EC}_{10}$ or $\log _{10} \mathrm{EC}_{20}$. 

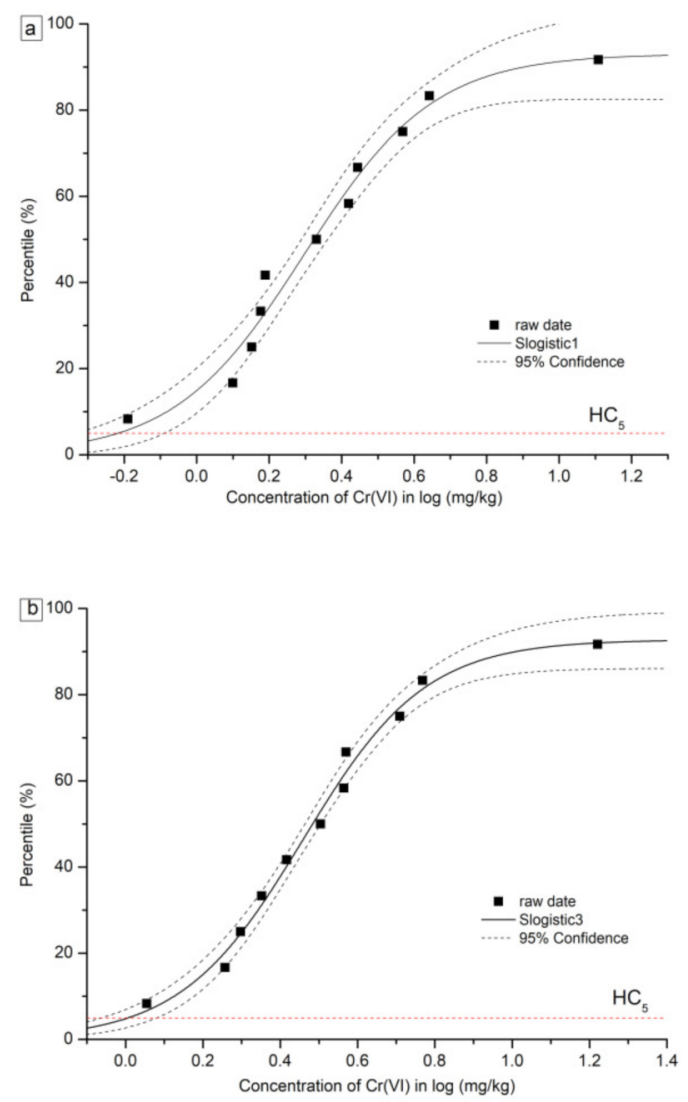

Figure 3. Curves of species sensitivity distribution for $\mathrm{Cr}$ (VI) based on (a) $\mathrm{EC}_{10}$, (b) $\mathrm{EC}_{20}$.
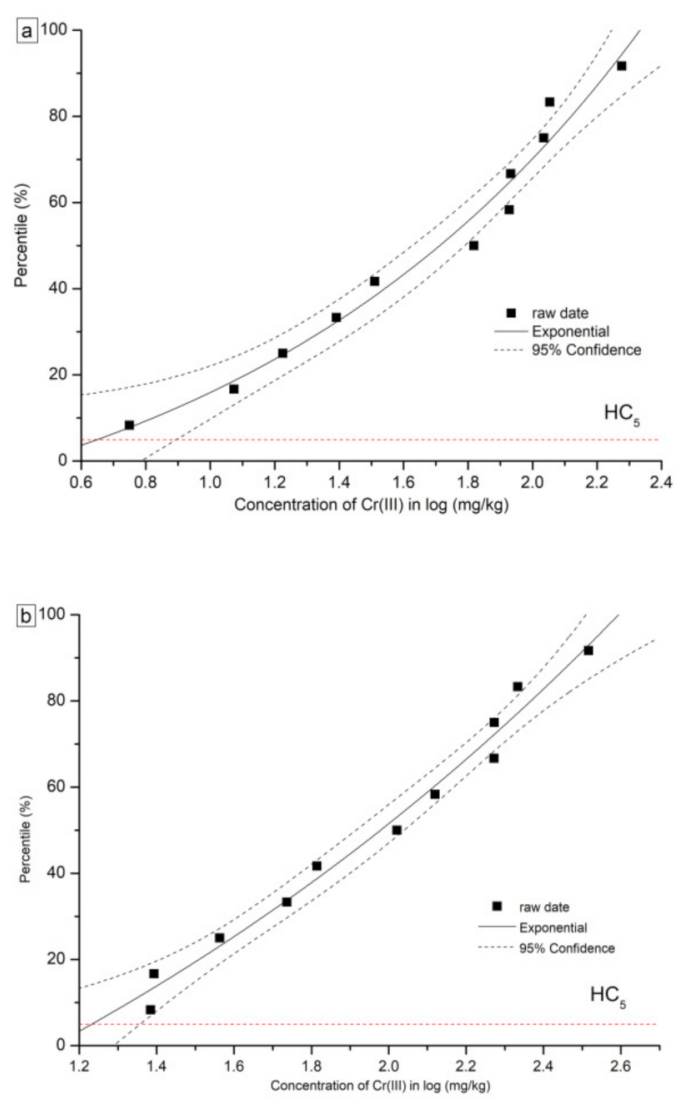

Figure 4. Curves of species sensitivity distribution for $\mathrm{Cr}$ (III) based on (a) $\mathrm{EC}_{10}$, (b) $\mathrm{EC}_{20}$. 


\section{Discussion}

Irrespective of $\mathrm{Cr}$ valence, the root growth of leafy vegetables, such as pakchoi cabbage and chive, was easily affected by $\mathrm{Cr}$ contamination. By contrast, the root growth of stem vegetables (e.g., celery) and root vegetables (e.g., radish) was less affected by $\mathrm{Cr}$ contamination. $\mathrm{Cr}$ contaminants generally damaged the root architecture of plants by limiting water and nutrient uptake efficiency [34], and induced a negative impact on the functioning of leaf photosynthetic machinery by reducing Fe and $\mathrm{Mg}$ uptake, which are essential for chlorophyll biosynthesis [35,36]. Photosynthesis was the physiological foundation for crop growth and was considered to be one of the most stress-sensitive processes [37]. Furthermore, $\mathrm{Cr}$ was found to be stable in roots and poorly translocated from roots to upper tissues. It is reported that the maximum amount of $\mathrm{Cr}$ is accumulated in the roots, followed by leaves and then fruits [38]. For radish, the root is the edible part and might accumulate a large amount of $\mathrm{Cr}$ by growing under highly $\mathrm{Cr}$-contaminated soil, which will result in a health risk though the food chain.

With respect to the $\mathrm{Cr}$ valence, the plant root growth was preferably impacted by $\mathrm{Cr}(\mathrm{VI})$ than $\mathrm{Cr}(\mathrm{III})$, since $\mathrm{Cr}(\mathrm{VI})$ produced lower $\mathrm{EC}_{10}$ and $\mathrm{EC}_{20}$ than $\mathrm{Cr}(\mathrm{III})$ did (Tables 3 and 4 ). Accordingly, the $\mathrm{HC}_{5}$ value derived from $\mathrm{EC}_{10}$ for $\mathrm{Cr}(\mathrm{VI})$ was $0.60 \mathrm{mg} / \mathrm{kg}$, which was lower than that for $\mathrm{Cr}(\mathrm{III})(4.51 \mathrm{mg} / \mathrm{kg})$, demonstrating that hexavalent $\mathrm{Cr}$ compounds were more hazardous than trivalent $\mathrm{Cr}$ compounds. It was reported that the uptake mechanisms of $\mathrm{Cr}(\mathrm{III})$ and $\mathrm{Cr}(\mathrm{VI})$ were quite different, $\mathrm{Cr}(\mathrm{VI})$ was immediately converted to $\mathrm{Cr}(\mathrm{III})$ in roots by $\mathrm{Fe}(\mathrm{IIII})$-reductase enzymes $[11,39,40]$, and plant tissues endured higher $\mathrm{Cr}(\mathrm{III})$ than $\mathrm{Cr}(\mathrm{VI})[13,40]$. Thus, the total $\mathrm{Cr}$ contents in soil do not necessarily reflect the biogeochemical behavior of $\mathrm{Cr}$ since the biogeochemical behavior of $\mathrm{Cr}$ differs with chemical speciation [21].

$\mathrm{Cr}$ speciation and its bio-organism transfer were governed by soil physico-chemical properties and microbial activity. From the southeast coast to northwest inland in China, the major soil types cover red soil, brown soil and cinnamon soil, which are quite different in terms of $\mathrm{pH}$, redox conditions, cation exchange capacity, biological and microbial conditions and co-existing competing cations. These soil types will differ significantly in $\mathrm{Cr}$ dynamic reactions and behaviors, including hydrolysis, oxidation, reduction and precipitation $[20,21]$, which lead to various $\mathrm{Cr}$ speciation and distribution. Shahid et al. (2017) indicated that toxic $\mathrm{Cr}(\mathrm{VI})$ might transform to less toxic $\mathrm{Cr}(\mathrm{III})$ in the presence of dissolved organic carbon originating from the solubilization of soil organic matter [21]. As a result, organic carbon can reduce $\mathrm{Cr}$ bioavailability and detoxify its negative effect on plant growth [40]. It is reported that the soil microbial community played a key role in governing $\mathrm{Cr}$ speciation [41], and $\mathrm{Cr}(\mathrm{VI})$ was able to interact with microorganisms via enzymatic biosorption, reduction and bioaccumulation [42]. The rate and extent of microbial-mediated $\mathrm{Cr}(\mathrm{VI})$ reduction greatly varied with bacterial strain, $\mathrm{Cr}$ concentration, as well as soil physio-chemical properties and co-existing contaminants [21,43]. As a result, soil screening values should be directly related to soil properties and conditions.

However, the Soil Environmental Quality Standards of China set the screening level values of $\mathrm{Cr}$ as $300 \mathrm{mg} / \mathrm{kg}$ for paddy fields and $200 \mathrm{mg} / \mathrm{kg}$ for dry land in the $\mathrm{pH}$ range of 6.5-7.5. These values are comparable to the values for the total $\mathrm{Cr}$ of Australia, the Netherlands and Thailand. A total of $200-300 \mathrm{mg} / \mathrm{kg}$ of $\mathrm{Cr}$ (III) in soil might not poison terrestrial plants, but $200-300 \mathrm{mg} / \mathrm{kg}$ of $\mathrm{Cr}(\mathrm{VI})$ exposure will pose a harmful impact on bio-organisms. Therefore, it is necessary to derive and formulate screening level values for different $\mathrm{Cr}$ oxidation states. Table 6 lists the soil quality standard values for $\mathrm{Cr}$ from different countries, and only a few countries (e.g., the United States, Japan, and Canada) have separated standard values for $\mathrm{Cr}(\mathrm{VI})$ and total $\mathrm{Cr}[22,32,44]$. Swedish, German, and Dutch soil quality standards are stringent and trying to minimize the impact on humans and surrounding ecosystems [45-47]. Therefore, there is no urgent need to revise existing limit values for these countries. The $\mathrm{HC}_{5}$ values of $\mathrm{Cr}(\mathrm{VI})$ based on the SSD-EC 10 and $\mathrm{HC}_{10}$ of $\mathrm{Cr}(\mathrm{VI})$ based on SSD-EC 10 in our experiments were higher than the screening level values in Japan, Canada and the United States [22,32,44]. However, the $\mathrm{HC}_{5}$ values of $\mathrm{Cr}(\mathrm{III})$ based 
on the SSD-EC 10 and $\mathrm{HC}_{10}$ of $\mathrm{Cr}(\mathrm{III})$ based on SSD-EC 10 were far less than the standard values of $\mathrm{Cr}$ in the other countries [45-49]. This may because the $\mathrm{EC}_{10}$ was close to acute NOECs or the tested species may be too sensitive to $\mathrm{Cr}$ (III). Moreover, the difference in the $\mathrm{HC}_{5}$ values between China and other countries might be attributed to the distribution of different resident species $[50,51]$. The unique taxonomic composition and complexity of ecosystems could lead to the over-protection or under-protection of terrestrial biorganisms therein. This suggests that the development of local soil quality criteria characterizing the sensitive species and potential risk acceptors in China is necessary.

Table 6. Risk-based screening levels of $\mathrm{Cr}$ in some countries $(\mathrm{mg} / \mathrm{kg})$.

\begin{tabular}{cccc}
\hline Country & Cr(VI) & Total Cr & Reference \\
\hline Australia & & 100 & NEPC, 1999 \\
Canada & 0.4 & 30 (sand), 60 (loam), 100 (clay) ${ }^{1}$ & CCME, 2006 \\
Germany & & 80 & FSPR, 1999 \\
Sweden & & 100 & Naturvårdsverket, 2009 \\
Netherlands & 0.29 & & RIVM, 1997 \\
United States & $0.05^{2}$ & & U.S. EPA, 2010 \\
Japan & & 300 & MEGJ \\
Thailand & 2.5 & 34 & PCD, 2004 \\
Belgium & & Carlon, 2007
\end{tabular}

Note: ${ }^{1}$ Germany differentiates metal limits according to soil properties; ${ }^{2}$ The unit is $\mathrm{mg} / \mathrm{L}$.

Soil heavy metal pollution has become a severe global problem. In light of a nationwide soil quality and pollution survey launched between 2006 and 2010 in China, overall $16.1 \%$ of soil was polluted, of which $82.2 \%$ was inorganic pollution, and Cr exceeding rates were $1.1 \%$ [52]. In order to enact scientific and practical soil quality standards, comprehensive soil surveys and advanced monitoring techniques are required, and it is essential to acquire the background concentration of elements, environmental quality, nutrient status, and physical and chemical properties of soils in the future. It is also highly practical to monitor the magnitude of the risks involved with the consumption of vegetables cultivated in contaminated soils. In order to have a better protection of the terrestrial ecosystem, it is essential to take the local geological and natural conditions of different land used into consideration. To meet the goals of protecting and conserving soil for sustainable use, a systematic soil quality standard, including national, regional and industrial soil quality, is advised to be developed. Studies on the regionalization of terrestrial ecological functions and potential risk acceptors and the collection of toxicity data will be ongoing.

\section{Conclusions}

The root inhibition rates of tested plants were positively correlated with either $\mathrm{Cr}(\mathrm{VI})$ or $\mathrm{Cr}$ (III) concentrations. Generally, leafy vegetables were the most sensitive plants to $\mathrm{Cr}$ contamination in soils, followed by solanaceous and stem vegetables. Gourd vegetables were the least sensitive plants. The $\mathrm{HC}_{5}$ values based on $\mathrm{EC}_{10}$ were $0.60 \mathrm{mg} / \mathrm{kg}$ for $\mathrm{Cr}(\mathrm{VI})$ and $4.51 \mathrm{mg} / \mathrm{kg}$ for $\mathrm{Cr}(\mathrm{III})$, and the $\mathrm{HC}_{10}$ values based on $\mathrm{EC}_{10}$ were $0.83 \mathrm{mg} / \mathrm{kg}$ for $\mathrm{Cr}(\mathrm{VI})$ and $16.98 \mathrm{mg} / \mathrm{kg}$ for $\mathrm{Cr}(\mathrm{III})$. Compared to the screening level values worldwide, the $\mathrm{HC}_{5}$ and $\mathrm{HC}_{10}$ values were higher for $\mathrm{Cr}(\mathrm{VI})$ and lower for $\mathrm{Cr}(\mathrm{III})$ to some extent. It is recommended that a scientific and practical soil quality standard should be developed to characterize the sensitive species and potential risk acceptors, considering chemical valence and species of target contaminants as well.

Author Contributions: Conceptualization, Y.L. and Q.Z.; methodology, Y.W. and S.C.; software, Y.L. and Y.W.; validation, Y.W.; formal analysis, Y.L. and Y.W.; investigation, Y.W. and S.C.; data curation, Y.W.; writing—original draft preparation, Y.L.; writing—review and editing, Y.L. and W.H.; visualization, Y.L. and Y.W.; supervision, Q.Z.; project administration, Q.Z.; funding acquisition, Y.L. and Q.Z. All authors have read and agreed to the published version of the manuscript. 
Funding: This research was funded by the National Natural Science Foundation of China, grant numbers 42007336 and 21677080.

Institutional Review Board Statement: Not applicable.

Informed Consent Statement: Not applicable.

Data Availability Statement: Data is contained within the article.

Conflicts of Interest: The authors declare no conflict of interest. The funders had no role in the design of the study; in the collection, analyses, or interpretation of data; in the writing of the manuscript, or in the decision to publish the results.

\section{References}

1. Kotaś, J.; Stasicka, Z. Chromium occurrence in the environment and methods of its speciation. Environ. Pollut. 2000, 107, 263-283. [CrossRef]

2. Turner, R.D.R.; Warne, M.S.J.; Dawes, L.A.; Vardy, S.; Will, G.D. Irrigated greywater in an urban sub-division as a potential source of metals to soil, groundwater and surface water. J. Environ. Manag. 2016, 183, 806-817. [CrossRef] [PubMed]

3. Srivastava, V.; Sarkar, A.; Singh, S.; Singh, P.; De Araujo, A.S.F.; Singh, R.P. Agroecological responses of heavy metal pollution with special emphasis on soil health and plant performances. Front. Environ. Sci. 2017, 5, 64. [CrossRef]

4. Gabarron, M.; Faz, A.; Martinez-Martinez, S.; Acosta, J. Change in metals and arsenic distribution in soil and their bioavailability beside old tailing ponds. J. Environ. Manag. 2018, 212, 292-300. [CrossRef]

5. Wang, M.; Liu, R.; Lu, X.; Zhu, Z.; Wang, H.; Jiang, L.; Liu, J.; Wu, Z. Heavy metal contamination and ecological risk assessment of swine manure irrigated vegetable soils in Jiangxi Province, China. Bull. Environ. Contam. Toxicol. 2018, 100, 634-640. [CrossRef]

6. Chen, C.W.; Lim, Y.C.; Chen, C.F.; Ju, Y.R.; Dong, C.D. Spatial distribution and ecological risk assessment of sediment metals in a highly industrialized coastal zone southwestern Taiwan. Environ. Sci. Pollut. Res. 2019, 26, 14717-14731. [CrossRef]

7. Ramos-Miras, J.J.; Gil, C.; Rodriguez, M.J.A.; Bech, J.; Boluda, R. Ecological risk assessment of mercury and chromium in greenhouse soils. Environ. Geochem. Health 2020, 42, 313-324. [CrossRef]

8. Rastmanesh, F.; Shalbaf, F.; Moradi, R.; Prinzhofer, A. Health risk assessment of heavy metals in Ahvaz oilfield using environmental indicators. Int. J. Environ. Sci. Technol. 2020, 17, 4669-4678. [CrossRef]

9. Richard, F.C.; Bourg, A.C.M. Aqueous geochemistry of chromium: A review. Water Res. 1991, 25, 807-816. [CrossRef]

10. Yu, X.Z.; Gu, J.D. Accumulation and distribution of trivalent chromium and effects on hybrid willow (Salix matsudana Koidz $\times$ alba L.). Metabolism. Arch. Environ. Contam. Toxicol. 2007, 52, 503-511. [CrossRef]

11. Zayed, A.; Lytle, C.M.; Terry, Q.N. Chromium accumulation, translocation and chemical speciation in vegetable crops. Planta 1998, 206, 293-299. [CrossRef]

12. do Nascimento, J.L.; de Almeida, A.A.F.; Barroso, J.P.; Mangabeira, P.A.; Ahnert, D.; Sousa, A.G.; Silva, J.V.S.; Baligar, V.C. Physiological, ultrastructural, biochemical and molecular responses of young cocoa plants to the toxicity of Cr (III) in soil. Ecotox. Environ. Saf. 2018, 159, 272-283. [CrossRef]

13. Sinha, V.; Pakshirajan, K.; Chaturvedi, R. Chromium tolerance, bioaccumulation and localization in plants: An overview. J. Environ. Manag. 2018, 206, 715-730. [CrossRef] [PubMed]

14. Wang, Y.T.; Shen, H. Bacterial reduction of hexavalent chromium. J. Ind. Microbiol. 1995, 14, 159-163. [CrossRef] [PubMed]

15. Montes, M.O.; Peralta-Videa, J.R.; Parsons, J.G.; Diaz, B.C.; Gardea-Torresdey, J.L. Spectroscopic determination of the toxicity, absorption, reduction, and translocation of Cr(VI) in two Magnoliopsida species. Int. J. Phytorem. 2013, 15, 168-187. [CrossRef] [PubMed]

16. Zhou, Q.X.; Huang, G.H. Environmental Biogeochemistry and Global Environmental Changes; Science Press: Beijing, China, 2001.

17. Fernandez, M.D.; Vega, M.M.; Tarazona, J.V. Risk-based ecological soil quality criteria for the characterization of contaminated soils. Combination of chemical and biological tools. Sci. Total Environ. 2006, 366, 466-484. [CrossRef]

18. Zhou, Q.X.; Teng, Y.; Liu, Y. A study on soil-environmental quality criteria and standards of arsenic. Appl. Geochem. 2017, 77, 158-166. [CrossRef]

19. Zhou, Q.X.; Luo, Y.; Zhu, L.Y. Scientific research on environmental benchmark values and rivision of national environmental standards in China. J. Agro-Environ. Sci. 2007, 26, 1-5. (In Chinese) [CrossRef]

20. Taghipour, M.; Jalali, M. Influence of organic acids on kinetic release of chromium in soil contaminated with leather factory waste in the presence of some adsorbents. Chemosphere 2016, 155, 395-404. [CrossRef] [PubMed]

21. Shahid, M.; Shamshad, S.; Rafiq, M.; Khalid, S.; Bibi, I.; Niazi, N.K.; Dumat, C.; Rashid, M.I. Chromium speciation, bioavailability, uptake, toxicity and detoxification in soil-plant system: A review. Chemosphere 2017, 178, 513-533. [CrossRef]

22. EPA, U.S. Regional Screening Levels for Chemical Contaminants at Superfund Sites; United States Environmental Protection Agency: Washington, DC, USA, 2010.

23. Hose, G.C.; Van den Brink, P.J. Confirming the species-sensitivity distribution concept for endosulfan using laboratory, mesocosm, and field data. Arch. Environ. Contam. Toxicol. 2004, 47, 511-520. [CrossRef]

24. Xin, Z.; Wenchao, Z.; Zhenguang, Y.; Yiguo, H.; Zhengtao, L.; Xianliang, Y.; Xiaonan, W.; Tingting, L.; Liming, Z. Species sensitivity analysis of heavy metals to freshwater organisms. Ecotoxicology 2015, 24, 1621-1631. [CrossRef] 
25. Wang, X.N.; Yan, Z.G.; Liu, Z.T.; Zhang, C.; Wang, W.; Li, H. Comparison of species sensitivity distributions for species from China and the USA. Environ. Sci. Pollut. Res. 2014, 21, 168-176. [CrossRef] [PubMed]

26. van Straalen, N.M. Threshold models for species sensitivity distributions applied to aquatic risk assessment for zinc. Environ. Toxicol. Pharmacol. 2002, 11, 167-172. [CrossRef]

27. Nagai, T.; Taya, K. Estimation of herbicide species sensitivity distribution using single-species algal toxicity data and information on the mode of action. Environ. Toxicol. Chem. 2015, 34, 677-684. [CrossRef] [PubMed]

28. Ali, N.A.; Ater, M.; Sunahara, G.I.; Robidoux, P.Y. Phytotoxicity and bioaccumulation of copper and chromium using barley (Hordeum vulgare L.) in spiked artificial and natural forest soils. Ecotox. Environ. Saf. 2004, 57, 363-374. [CrossRef]

29. López-Luna, J.; González-Chávez, M.C.; Esparza-García, F.J.; Rodríguez-Vázquez, R. Toxicity assessment of soil amended with tannery sludge, trivalent chromium and hexavalent chromium, using wheat, oat and sorghum plants. J. Hazard. Mater. 2009, 163, 829-834. [CrossRef] [PubMed]

30. Wong, M.H.; Bradshaw, A.D. A comparison of the toxicity of heavy metals, using root elongation of rye grass, Lolium perenne. New Phytol. 1982, 91, 255-261. [CrossRef]

31. Lu, R. Analytical Methods for Soils and Agricultural Chemistry; China Agricultural Science and Technology Press: Beijing, China, 1999.

32. CCME. A Protocol for the Derivation of Environmental and Human Health Soil Quality Guidelines; Canadian Council of Ministers of the Environment: Winnipeg, MB, Canada, 2006.

33. Schroer, A.F.W.; Belgers, J.D.M.; Brock, C.M.; Matser, A.M.; Maund, S.J.; Brink, P.J.V.D. Comparison of laboratory single species and field population-level effects of the pyrethroid insecticide $\lambda$-cyhalothrin on freshwater invertebrates. Arch. Environ. Contam. Toxicol. 2004, 46, 324-335. [CrossRef]

34. Kamran, M.; Wang, D.; Alhaithloul, H.A.S.; Alghanem, S.M.; Aftab, T.; Xie, K.; Lu, Y.; Shi, C.; Sun, J.; Gu, W.; et al. Jasmonic acid-mediated enhanced regulation of oxidative, glyoxalase defense system and reduced chromium uptake contributes to alleviation of chromium (VI) toxicity in choysum (Brassica parachinensis L.). Ecotox. Environ. Saf. 2021, 208, 111758. [CrossRef]

35. Kumar, P.; Tokas, J.; Singal, H.R. Amelioration of chromium(VI) toxicity in Sorghum (Sorghum bicolor L.) using glycine betaine. Sci. Rep. 2019, 9, 16020. [CrossRef]

36. Ulhassan, Z.; Gill, R.A.; Huang, H.; Ali, S.; Mwamba, T.M.; Ali, B.; Huang, Q.; Hamid, Y.; Khan, A.R.; Wang, J.; et al. Selenium mitigates the chromium toxicity in Brassicca napus L. by ameliorating nutrients uptake, amino acids metabolism and antioxidant defense system. Plant Physiol. Biochem. 2019, 145, 142-152. [CrossRef] [PubMed]

37. Huang, M.; Ai, H.; Xu, X.; Chen, K.; Niu, H.; Zhu, H.; Sun, J.; Du, D.; Chen, L. Nitric oxide alleviates toxicity of hexavalent chromium on tall fescue and improves performance of photosystem II. Ecotox. Environ. Saf. 2018, 164, 32-40. [CrossRef] [PubMed]

38. Singh, H.P.; Mahajan, P.; Kaur, S.; Batish, D.R.; Kohli, R.K. Chromium toxicity and tolerance in plants. Environ. Chem. Lett. 2013, 11, 229-254. [CrossRef]

39. Depault, F.; Cojocaru, M.; Fortin, F.; Chakrabarti, S.; Lemieux, N. Genotoxic effects of chromium(VI) and cadmium(II) in human blood lymphocytes using the electron microscopy in situ end-labeling (EM-ISEL) assay. Toxicol. Vitro 2006, 20, 513-518. [CrossRef] [PubMed]

40. Riaz, M.; Yasmeen, T.; Arif, M.S.; Ashraf, M.A.; Hussain, Q.; Shahzad, S.M.; Rizwan, M.; Mehmood, M.W.; Zia, A.; Mian, I.A.; et al. Variations in morphological and physiological traits of wheat regulated by chromium species in long-term tannery effluent irrigated soils. Chemosphere 2019, 222, 891-903. [CrossRef]

41. Ma, Y.; Rajkumar, M.; Zhang, C.; Freitas, H. Beneficial role of bacterial endophytes in heavy metal phytoremediation. J. Environ. Manag. 2016, 174, 14-25. [CrossRef]

42. Tekerlekopoulou, A.G.; Tsiflikiotou, M.; Akritidou, L.; Viennas, A.; Tsiamis, G.; Pavlou, S.; Bourtzis, K.; Vayenas, D.V. Modelling of biological $\mathrm{Cr}(\mathrm{VI})$ removal in draw-fill reactors using microorganisms in suspended and attached growth systems. Water Res. 2013, 47, 623-636. [CrossRef]

43. Otitoloju, A.A. Relevance of joint action toxicity evaluations in setting realistic environmental safe limits of heavy metals. J. Environ. Manag. 2003, 67, 121-128. [CrossRef]

44. MEGJ. Environmental Quality Standards for Soil Pollution; Ministry of the Environment, Government of Japan (MEGJ): Tokyo, Japan, 2001.

45. RIVM. Maximum Permissible Concentrations and Negligible Concentrations for Metals, Taking Background Concentrations into Account; National Institute of Public Health and Environment: Bilthoven, The Netherlands, 1997.

46. FSPR. Precaution Values for Soils Pursuant to 8 Paragraph Ederal Soil Protection Law; Federal Soil Protection and Contaminated Sites Ordiance (BBodSchV): Hannover, Germany, 1999.

47. Naturvårdsverket. Nya Generella Riktvärden för Förorenad Mark. 2009. Available online: www.naturvardsverket.se/ebh (accessed on 12 October 2020).

48. NEPC. Guidelines on Healthbased Investigation Levels; National Environmental Protection Council (NEPC): Sydney, Australia, 1999.

49. PCD. Soil Quality Standard for Habitat and Agriculture. Pollution Control Department of Thailand (PCD). Notification of National Environmental Board No. 25. 2004. Available online: http://www.pcd.go.th/info_serv/en_reg_std_soil01.html\#s1 (accessed on 12 October 2020).

50. He, J.; He, H.; Yan, Z.; Gao, F.; Zheng, X.; Fan, J.; Wang, Y. Comparative analysis of freshwater species sensitivity distributions and ecotoxicity for priority pesticides: Implications for water quality criteria. Ecotox. Environ. Saf. 2019, 176, 119-124. [CrossRef] 
51. Sorgog, K.; Kamo, M. Quantifying the precision of ecological risk: Conventional assessment factor method vs. species sensitivity distribution method. Ecotox. Environ. Saf. 2019, 183, 109494. [CrossRef] [PubMed]

52. China. The National Soil Pollution Survey Bulletin. Ministry of Environmental Protection and Ministry of Land and Resources of P. R. China. 2014. Available online: http:/ / www.sdpc.gov.cn/fzgggz/ncjj/zhdt/201404/t20140418_607888.html (accessed on 12 October 2020). (In Chinese) 